\title{
STABILITAS SUSPENSI JUS KELAPA MUDA TERHADAP PENAMBAHAN KARAGINAN
}

\author{
Hadiono Soegeng Rahardjo*, Tri Adhi Santoso \\ Akademi Entrepreneurship Terang Bangsa \\ Jl. Arteri Utara, Kompleks Grand Marina, Semarang, 50144. \\ "Email:hadiono@entrepreneurship-terangbangsa.ac.id
}

\begin{abstract}
Abstrak
Perkembangan minuman kekinian di Indonesia terus bertumbuh pesat dengan annual growth 7,76\% (BPS,2019). Umumnya minuman yang berkembang adalah minuman berkabonasi, kopi, buble serta jus buah. Mengingat Indonesia sebagai negara dengan area penghasil kelapa terluas di dunia mencapai 3,7 juta hektar dengan total produksi 17.100 miliar butir per tahun. Ini dapat menjadi pertimbangan untuk memunculkan minuman kekinian dari kelapa muda. Kandungan asam lemak omega 6 dan omega 9 dalam daging kelapa muda cukup tinggi 30-40\%. Ini dapat menjadi salah satu alternatif minuman kekininan yang membantu kecerdasan otak. Kandungan buah kelapa adalah air, protein dan lemak sehingga apabila dibuat jus kelapa muda akan sangat mudah terpisah. Untuk dapat menstabilkan suspensi jus kelapa muda maka perlu dilakukan penelitian dengan menambahkan bahan pensuspensi. Berdasarkan beberapa pertimbangan maka dipilih bahan yang alami yaitu karaginan yang merupakan ekstrak dari rumput laut. Hasil penelitian menunjukkan bahwa kondisi stabilitas suspensi jus kelapa muda terbaik pada konsentrasi kelapa muda $20 \%$ (w/w) dengan penambahan bahan pensuspensi karaginan kappa pada konsentrasi $0,3 \%$ (w/w). Karaginan kappa mempunyai sifat larut dalam air dan cenderung mengembang (swelling) mampu sebagai bahan pensuspensi alamiah pada jus kelapa muda.
\end{abstract}

Kata kunci : karaginan, kelapa muda, stabilitas suspensi.

\section{PENDAHULUAN}

Kelapa atau Cocos nucifera L., banyak tumbuh di daerah tropis dan subtropis seperti Indonesia dan Filipina serta mempunyai banyak kegunaan (Arisht dkk., 2019). Indonesia memiliki areal tanaman kelapa terluas di dunia, yaitu 3,7 juta hektar dengan total produksi 17.100 miliar butir/tahun (Rindengan dkk., 2015). Daging buah kelapa menunjukkan perbedaan kandungan asam lemak pada kelapa muda dan kelapa tua, (Hayati, 2009), dimana kelapa muda mempunyai kandungan terbesar $\mathrm{C}_{18.1}$ asam lemak oleat $=38,3 \%, \mathrm{C}_{18.2}$ asam lemak linoleat $=32,6 \%$ dan $\mathrm{C}_{16.0}$ asam lemak palmitat $=22,5 \%$, sedangkan kelapa tua mempunyai kandungan C12.0 asam lemak laurat $=48 \%$, dan C14.0 asam lemak miristat $=$ $21.8 \%$

Asam oleat $\mathrm{C}_{18} \mathrm{H}_{34} \mathrm{O}_{2}$ merupakan asam lemak tidak jenuh, asam linoleat $\mathrm{C}_{18} \mathrm{H}_{30} \mathrm{O}_{2}$ merupakan asam lemak tidak jenuh majemuk yang dikenal dengan asam lemak Omega-3 dan Omega-6 (Kris dkk., 2004). Keduanya merupakan asam lemak esensial yang tidak dapat dimetabolisme oleh tubuh manusia dan sangat diperlukan untuk memenuhi fungsi fisiologi tubuh. Asam lemak Omega 6 akan dimetabolisme menjadi asam arakidonat (AA) yang menunjang kecerdasan otak (Boediarti, 2000).

Protein daging buah dan air buah kelapa muda mengandung lebih dari 15 asam amino esensial (Rindengan, 2004). Bagi tubuh manusia ada 10 jenis asam amino esensial yang harus dipenuhi dari makanan sehari-hari diantaranya Threonin (THR), Tirosin (TYR), Methionin (MET), Valin (VAL), Fenilalamin (PHE), Ileusin (ILE), Leusin (LEU), Lisin (LYS), Histidin (HIS), dan Arganin (ARG) (Rindengan, 2004). Kandungan asam amino Glutamat (GLU) pada daging buah 3,83\% dan pada air buah $14,5 \%$ yang tertinggi dibandingkan dengan kandungan asam amino lainnya. Sehingga dengan mengkonsumsi jus kelapa muda maka tubuh akan menerima asupan asam amino sebagai nutrisi otak.

Ketika buah kelapa belum matang disebut kelapa muda dapat dipanen juga untuk diminum sebagai air kelapa dan dibuat menjadi jus kelapa muda (Teixeira, 2019)Daging kelapa muda mengandung lemak $6,44 \%$, karbohidrat $5,46 \%$, protein $1,49 \%$, serta serat kasar $2,70 \%$. Ketika daging buah dan air buah kelapa muda diblender untuk memperoleh jus kelapa muda, maka akan terbentuk jus kelapa muda yang heterogen, tidak stabil dan mudah terpisahkan. 
Kelapa muda tidak dapat terdispersi dalam larutan sehingga terbentuk suspensi. Untuk dapat menstabilkan suspensi jus kelapa muda maka perlu ditambahkan suspension agent . Pada penelitian ini akan digunakan karaginan terhadap kestabilan suspensi jus kelapa muda.

Melalui hasil penelitian ini diharapkan dapat mengetahui pengaruh konsentrasi bahan pensuspensi karaginan terhadap kestabilan suspensi jus kelapa muda, Penelitian ini diharapkan dapat dipakai untuk mempertimbangan memunculkan minuman kekinian yang segar dan mempunyai manfaat kesehatan.

\section{METODOLOGI}

\subsection{Bahan}

Bahan yang digunakan dalam penelitian ini adalah kelapa muda yang berumur sekitar 8 bulan didapatkan dari pasar tradisional setempat, dan karaginan kappa dari CV. Karagen Indonesia.

\subsection{Alat}

Alat yang digunakan dalam penelitian ini adalah blender Philips HR 2116, timbangan analitik $(600 \mathrm{~g} / 0,01 \mathrm{~g})$, gelas ukur $(250 \mathrm{ml})$, dan peralatan gelas.

\subsection{Persiapan Bahan}

Kelapa muda yang dipilih berkisar umur 8 bulan. Buka tempurung kelapa dan pisahkan air dan daging kelapa muda. Untuk variabel daging kelapa muda $10 \%$, timbang 25 gram daging kelapa muda kemudian tambahkan air kelapa hingga 250 gram. Sedangkan untuk variabel daging kelapa muda $20 \%$, timbang 50 gram daging kelapa muda kemudian tambahkan air kelapa hingga 250 gram.. Varaibel bahan pensuspensi kappa karaginan yang ditambahkan sesesuai variable adalah $0,1 \%, 0,2 \%, 0,3 \%$ dan $0,4 \%$, atau dalam satuan masa sebesar 0,25 gram, 0,50 gram, 0,75 gram, dan 1,00 gram.

\subsection{Metode Pengolahan}

Percobaan dilakukan pada jus kelapa muda dengan konsentrasi $10 \%$ dan $20 \%$ terhadap karaginan dengan konsentrasi $0,1 \%$; $0,2 \% ; 0,3 \%$ dan $0,4 \%$. Setiap percobaan dilakukan 2 kali. Setelah semua bahan dicampur kemudian lakukan proses penderaan dengan blender selama 1 menit. Kemudian jus kelapa muda dituang ke dalam gelas ukur 250 $\mathrm{ml}$ dan dilakukan pengamatan pada awal, setelah 5, 10, 15, 20, 25, dan 30 menit. Pengamatan dilakukan terhadap volume cairan yang terpisah dari larutan suspensi.

\subsection{Stabilitas Suspensi.}

Kendala yang dihadapi pada proses pembuatan suspensi adalah dengan menjaga agar partikel padatan yang heterogen tidak cepat terpisahkan dari larutan. Untuk itu diperlukan satu tindakan untuk menjaga stablitas suspensi. Berdasarkan Hukum Stokes, dapat diketahui beberapa faktor yang mempengaruhi stabilitas suspensi.

$$
V=\frac{d^{2}\left(\rho-\rho_{0}\right) g}{\eta}
$$

$$
\begin{aligned}
& \text { Keterangan : } \\
& \begin{aligned}
\mathrm{V} & =\text { kecepatan sedimentasi, } \mathrm{cm} / \text { detik } \\
\mathrm{d} & =\text { diameter partikel padatan, } \mathrm{cm} \\
\rho & =\text { berat jenis partikel, } \mathrm{g} / \mathrm{cm}^{3} \\
\rho_{0} & =\text { berat jenis cairan, } \mathrm{g} / \mathrm{cm}^{3} \\
\mathrm{~g} & =\text { gaya gravitasi, } \mathrm{cm} / \mathrm{detik}^{2} \\
\eta & =\text { viskositas, poise }
\end{aligned}
\end{aligned}
$$

Agar partikel padatan tetap terdistribusi merata maka ada beberapa faktor yang perlu untuk mendapat perhatian, diantaranya :

a. diameter padatan harus semakin kecil agar kecepatan fluidanya rendah. Untuk memperkecil diameter padatan dapat dipakai blender, mixer, homogeniser atau peralatan agitasi lainnya.

b. viskositas larutan dapat dinaikkan agar kecepatan fluidanya rendah. Viskositas larutan dipengaruhi oleh konsentrasi padatan, dan viskositas larutann itu sendiri. Dengan demikian untuk menaikkan viskositas larutan diperlukan suspending agent. Bahan yang diperlukan untuk menstabilkan suspensi dapat dipilih berdasarkan kesesuaian secara kimia terhadap bahan-bahan yang lain dalam larutan suspensi tersebut. Bahan yang diperlukan untuk menstabilkan suspensi dapat dipilih berdasarkan kesesuaian secara kimia terhadap bahan-bahan yang lain dalam larutan suspensi tersebut (Farikha dkk., 2013). .

Stabilitas suspensi adalah kemampuan untuk mempertahankan volume maksimum dan biasanya diukur dengan tingkat dan / atau jumlah cairan yang terpisah dari suspensi. 
Stabilitas suspensi $(\%)=\frac{V-V_{t}}{V} \times 100 \%$

Keterangan :

$\mathrm{V}=$ volume mula-mula suspensi, $\mathrm{cm}^{3}$

$\mathrm{V}_{\mathrm{t}}=$ volume cairan yang terpisah dari suspensi, $\mathrm{cm}^{3}$ selama waktu $\mathrm{t}$ menit

\subsection{Analisis Statistik}

Pengolahan data variabel hasil penelitian digunakan analysis of variant (ANOVA) melalui program Microsoft Excel 2016. Data stabilitas suspensi jus kelapa muda terhadap waktu dilakukan analisis Two-Factor Without Replication ANOVA pada data terdistribusi normal dan homogen dengan tingkat signifikansi $95 \%$.

\section{HASIL DAN PEMBAHASAN}

Perlakukan penambahan karaginan kappa dengan konsentrasi yang sangat kecil pada jus kelapa muda memberikan pengaruh nyata terhadap stablitas suspensi jus kelapa muda tersebut. Hal ini disebabkan karena karaginan kappa yang mudah larut dalam air dingin serta mempunyai sifat cenderung mengembang (swelling).

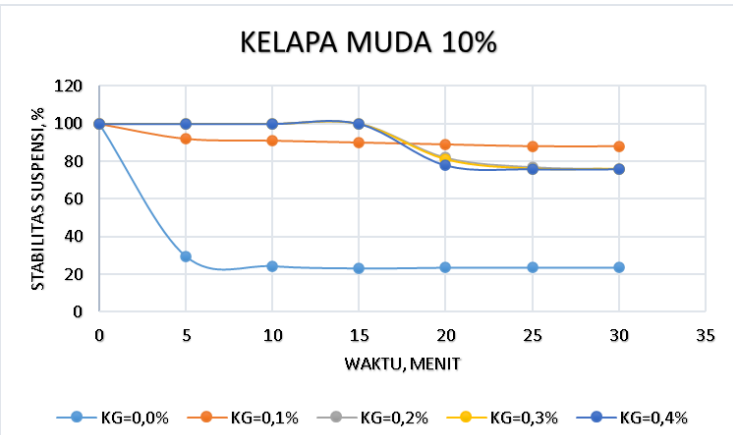

\section{Gambar 1. Stabilitas suspensi jus kelapa muda dengan konsentrasi $10 \%$}

Pada gambar 1. menunjukkan bahwa dengan bertambahnya konsentrasi karaginan sangat berpengaruh pada kestabilan suspensi jus kelapa muda, Pada jus kelapa muda dengan konsentrasi $10 \%$ dengan bertambahnya konsentrasi karaginan kappa maka stabilitas supensi semakin bertambah, namun stabilitas akan sedikit menurun pada penambahan karaginan kappa 0,3\% dan 0,4\% setelah menit ke 15. Hal ini disebabkan karena rendahnya konsentrasi kelapa muda sedangkan semakin besar karaginan kappa membutuhkan reaktivitas dengan protein yang berasal dari kelapa muda. Sehingga terjadi interaksi elektrostatik yang kuat antara gugus ester sulfat dalam molekul karaginan yang bermuatan negatif dengan residu asam amino dalam protein kelapa muda yang bermuatan positif. Hal ini sesuai dengan Hotchkiss dkk (2016) yang menyatakan reaktivitas karaginan dengan protein dipengaruhi banyak faktor seperti konsentrasi karaginan, jenis protein, suhu, $\mathrm{pH}$ dan titik isoelektrik protein. Stabilitas suspensi jus kelapa muda 10\% dengan penambahan karaginan kappa $0,1 \% ; 0,2 \% ; 0,3 \%$ dan $0,4 \%$.

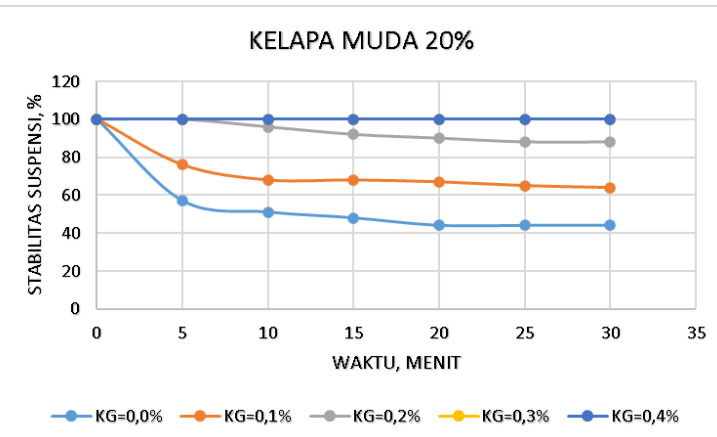

\section{Gambar 2. Stabilitas suspensi jus kelapa muda dengan konsentrasi $20 \%$.}

Namun pada pengamatan jus kelapa muda konsentrasi $20 \%$ dengan penambahnan karaginan kappa maka stabilitas suspensi semakin bertambah. Kondisi optimal terjadi pada penambahan karaginan kappa $0,3 \%$ dan mampu bertahan stabil lebih dari 30 menit seperti terlihat pada gambar 2 .

\section{KESIMPULAN}

Hasil penelitian menunjukkan bahwa kondisi stabilitas suspensi jus kelapa muda terbaik pada konsentrasi daging kelapa muda $20 \%(\mathrm{w} / \mathrm{w})$ dengan penambahan bahan pensuspensi karaginan pada konsentrasi 0,3\% $(\mathrm{w} / \mathrm{w})$. Karaginan kappa mempunyai sifat larut dalam air dan cenderung mengembang (swelling) mampu bahan pensuspensi alamiah pada jus kelapa muda.

\section{DAFTAR PUSTAKA}

Arisht, S.N., Abdul, P.M., Liu, C.M., Lin, S.K. Maaroff, R.M., Wu, S.Y., and Jahim, M,D., (2019), Biotoxicity Assessment And Lignocellulosic Structural Changes of Phosphoric Acid Pre-Treated Young Coconut Husk Hydrolysate For Biohydrogen Production, International Journal Of Hydrogen Energy, 44, pp.5830-5843.

Boediarti. (2000). Omega 6 dan Omega 3 Untuk Tumbuh Kembang Otak. Nutrition 
Review. Edisi Khusus. PT. Sari Husada, 1-2.

Farikha, I.N., Anam, C., dan Widowati, E., (2013), Pengaruh Jenis Dan Konsentrasi Bahan Penyetabil Alami Terhadap Karakteristik Fisikokimia Sari Buah Naga Merah (Hylocereus Polyrhizus) selama peyimpanan, Jurnal Teknosains Pangan, 2(1), pp.30-38.

Hayati, R., (2009), Perbandingan Susunan dan Kandungan Asam Lemak Kelapa Muda dan Kelapa Tua Dengan Metode Gas Kromatografi, Jurnal Floratek, 4, pp.1828.

Hotchkiss, S.., Brooks, M., Campbell, R., Philp, K., and Trius, A., (2016), The Use Of Carrageenan in Food, Chapter 10, Nova Science Publishers.Inc.Ireland, pp.229243.

Kris-Etherton, P.M., Hecker, K.D., and Binkoski, A.E., (2004), Polyunsaturated Fatty Acids and Cardiovascular Health, Nutrition Reviews, 62(11), pp.414-426.

Rindengan, B., (2004), Potensi Buah Kelapa Muda Untuk Kesehatan dan Pengolahannya, Jurnal Prespektif. 3, pp.46-60.

Rindengan, B., (2015), Ekstrak Galaktomanan Pada Daging Buah Kelapa Dan Ampasnya Serta Manfaatnya Untuk Pangan, Jurnal Prespektif, 14(1), 37-49.

Teixeira, N.S., Turrezan, R., Freitas, D.D.G.S., Pontes, S.M., Ribeiro, L.O., Cabral, L.M.C., and Matta, V.M., (2019), Development of A Fruit Smoothie With Solid Albumen Of Green Coconut, Food Technology Ciencia Rural, 49(1), pp.1-8. 